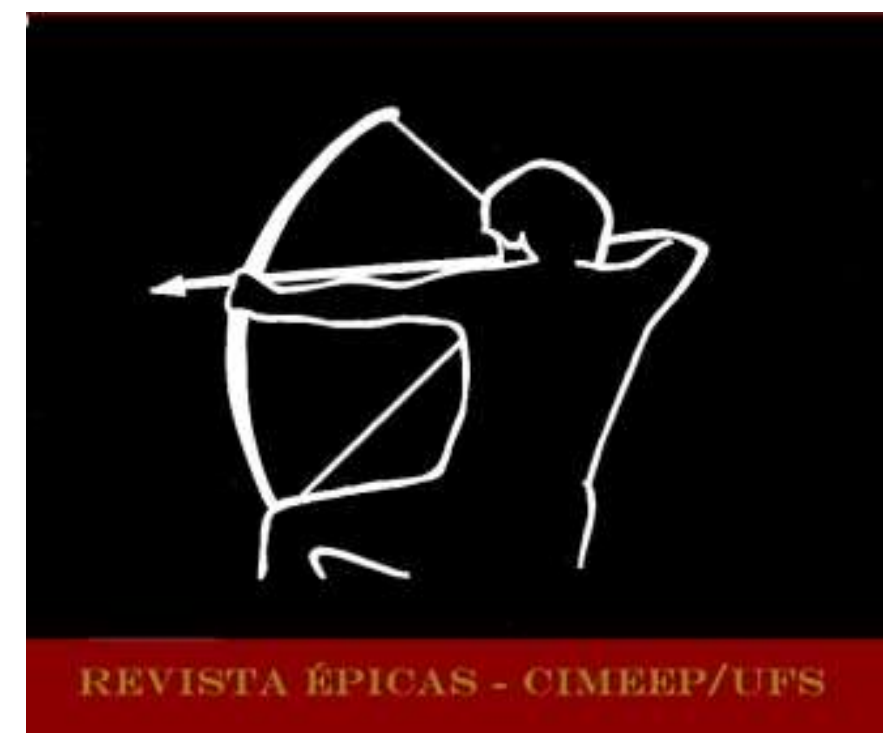

OLIVEIRA, Ellen. Aspectos épicos em "Os gatos" e "Remédio" (1949), de Fernandes Barbosa. In: Revista Épicas. Ano 4, N. 8, Dez 2020, p. 138-166. ISSN 2527-080-X. DOI: http://dx.doi.org/10.47044/2527-080X.2020v8.138166

\title{
ASPECTOS ÉPICOS EM OS “GATOS” E O “REMÉDIO” (1949), DE FERNANDES BARBOSA ${ }^{1}$
}

\section{ASPECTS ÉPIQUES DANS LES “CHATS” ET LE “REMÈDE” (1949), PAR FERNANDES BARBOSA}

Ellen dos Santos Oliveira Universidade Federal de Sergipe/CAPES

RESUMO: Este trabalho analisa os aspectos épicos em Os "Gatos" e o "remédio" (1949), de Fernandes Barbosa, um livro de poemas que satiriza os feitos de personagens políticos do Brasil da primeira metade do século XX, e exalta a heroicidade do cidadão honesto, personificado no personagem "Pato", um herói coletivo que resiste em meio ao discurso do fascismo e da corrupção em um cenário marcado por guerras e crises políticas, financeiras e moral. Embora o autor não deixe evidente a intenção épica, na leitura da obra nos identifica-se os aspectos épicos. A metodologia utilizada é a Análise Literária a partir dos fundamentos críticos teóricos contemporâneos desenvolvidos e propostos por Ramalho (2013), em especial no que diz respeito as categorias dos aspectos épicos que serão analisados, são eles: proposição, invocação, divisão em cantos, plano histórico, plano literário, plano maravilhoso, heroísmo épico. Pretende-se com este estudo contribuir com os estudos contemporâneos sobre: o Gênero Épico, desenvolvidos pelo CIMEP - Centro Internacional e Multidisciplinar de Estudos Épicos da UFS; a literatura produzida no período das Guerras mundiais, e que contribuem para pensar sobre questões sócio-políticas decorrentes das consequências delas; a literatura brasileira produzida no século XX; a poética de Nilo Fernandes Barbosa (1910-1988). Palavras-chave: Gênero Épico. Fernandes Barbosa. Os "Gatos" e o "remédio" (1949).

\footnotetext{
1 "O presente trabalho foi realizado com apoio da Coordenação de Aperfeiçoamento de Pessoal de Nível Superior - Brasil (CAPES) - Código de financiamento 001".
} 
RÉSUMÉ: Cet ouvrage analyse les aspects épiques d' Les "chats" et le "remède" (1949), de Fernandes Barbosa, un livre de poèmes qui fait la satire des actes des personnages politiques du Brésil dans la première moitié du 20e siècle, et exalte l'héroïsme du citoyen honnête, incarné dans le personnage "Pato", un héros collectif qui résiste au milieu du discours du fascisme et de la corruption dans un scénario marqué par les guerres et les crises politiques, financières et morales. Bien que l'auteur ne fasse pas apparaître l'intention épique, dans la lecture de l'ouvrage nous identifions les aspects épiques. La méthodologie utilisée est l'analyse littéraire basée sur les fondements théoriques critiques contemporains développés et proposés par Ramalho (2013), notamment en ce qui concerne les catégories d'aspects épiques qui seront analysés, ce sont: proposition, invocation, division en coins, plan plan historique, littéraire, plan merveilleux, héroïsme épique. Cette étude vise à contribuer à des études contemporaines sur: le genre épique, développé par le CIMEP - Centre international et multidisciplinaire d'études épiques à I'UFS; la littérature produite pendant les guerres mondiales et qui contribue à la réflexion sur les enjeux sociopolitiques qui en découlent; Littérature brésilienne produite au 20e siècle; la poésie de Nilo Fernandes Barbosa (1910-1988).

Mots-clés: Genre Épique. Fernandes Barbosa. Les "chats" et le "remède" (1949).

\section{Introdução}

Em 2019 completou 70 anos da publicação da primeira e única edição de Os "Gatos" e o "Remédio" (1949), de Fernandes Barbosa. Uma obra em que o poeta, não apenas, satiriza os costumes e vícios durante a crise após o Estado Novo e o engajamento antiépico e antiético de personagens políticos corruptos após a Segunda Guerra Mundial (1939 - 1945), mas também, aproveitando a pena da lírica, e revelando seu espírito épico, para exaltar a honestidade do povo brasileiro personificado no personagem silenciado "Pato", um herói coletivo que resiste à corrupção e sobrevive ao fascismo, mesmo diante de situações que põe em xeque o heroísmo humano diante de crises financeiras, políticas e morais.

Captando o espírito crítico e descontentamento do poeta com o cenário político da época, assim diz o prefaciador da obra Lamartine Souza, comparando o Brasil com a França:

Certo jornalista francês, refugiado em Londres, tentou explicar, em livro recente, as razões que, na sua opinião, determinaram a queda de sua patria, na segunda guerra mundial. E atribue, perentóriamente, a dèbacle, à caterva de políticos que, na ânsia incontida de angariar votos e posições, falavam ao povo, fazendoIhe falazes promessas absurdas. Explicavam, à massa, os seus direitos, sem nunca aludir aos seus deveres. E se instituiu, em consequência, na França, a glorificação da preguiça. $O$ trabalho útil e produtivo passou a ser uma ignomínia. Estou certo de que Fernandes Barbosa, si vivesse atualmente em París, teria escrito o seu libelo em francês. Mas, por circunstâncias tirânicas, publica-o em português, para os leitores do Brasil.

Sempre se ouviu dizer, e já se tornou banal, por força da repetição, que a degradação de um país se processa por ação centrífuga. Ou age em sentido vertical, de cima para baixo. (sic. SOUZA, in. FERNANDES BARBOSA, 1949). 
Embora não tenha sido publicado na França, Os "Gatos" e o "Remédio" (1949) chegou às mãos de amigos estrangeiros, repercutindo no cenário internacional, tendo como recepção crítica o poeta uruguaio Julio Casas Araujo que assim escreveu sobre a obra:

Admirado poeta Fernández Barbosa:

Por manos amiga me llega su libro "Os Gatos e os remédios", titulo que previene su desnuda ironia.

Los temas y los hombres, lugareños cobran, em sus versos, tono universal, por su viviente humanidade.

Dura punta esa que lastima el trezo del caricato; $y$, sin embargo, no si dissimula, detrás, su alma herida, por tanta injusticia y tanta dolor ajeno. Su espirito fraternal palpita, adolorido, em esse libro que no logra ocutar su própria pena. Ya veo com quanto afán procuraram apagar su eficacia demolidora. Pero los humildes bejarám su mano y se abrigaran a la sombra tutelar de su noble corazon.

Quiárame sua amigo y admirador, al entrejarle ambas manos fraternas. (Julio Casas Araujo)

No cenário brasileiro, a recepção da obra não foi diferente. Leitores compartilharam o mesmo espírito crítico do poeta e, alguns, ainda esboçaram comentários que levantaram questionamentos sobre a estética da obra, principalmente no que diz respeito ao gênero. Os perfis dos leitores variam entre: historiador e crítico literário, como Walter Spalding; a jornalista e professor de literatura, como Mildo Fenner; religiosos, como o padre Pedro Luiz; entre outros.

No ano em que a obra foi publicada o Correio do Sul publicou a seguinte nota, classificando a obra como um "caderno de sonetos":

“OS GATOS E O REMÉDIO" é um interessante caderno de sonêtos de autoria do festejado e consagrado poeta gaúcho Fernandes Barbosa. Dotado de uma técnica primorosa e um conhecimento seguro da arte do verso, aliado a uma fina sensibilidade e sutil ironia, o poeta consegue através de suas estrofes, cuidadosamente buriladas, uma caricatura das mais felizes e expressivas do estado de coisas em que se encontra o povo brasileiro (sic.CORREIO DO SUL,1949. In. FROTA, Aquino; MESQUITA, Oliveira; SPALDING, Walter, et al., ?).

Já Aquino Frota põe em evidência "o gênero de poesia" ou o difícil estilo poético, cultivado pelo poeta. E, ainda, justifica a atitude musa insatisfeita e, com isso, lembrando as musas que inspiravam os poetas das epopeias clássicas. Vejamos abaixo:

O gênero de poesia dos seus "GATOS" é o mais difícil do que o cultivado por adolescentes enamorados. A sua musa não se satisfaz com a sensibilidade, e 
toma atitudes, combate, ridiculariza os que já transformaram suas vidas em epigrama. Assim, precisa reunir o senso do pensador político à música das estrofes. E o seu livro não só o consegue, como acrescenta a isso o humor, a ironia, com expressão natural de um observador das "belezas" de nosso panorama político (FROTA, In. FROTA, Aquino; MESQUITA, Oliveira; SPALDING, Walter, et al., ?).

Um leitor de alma sensível foi o Padre Pedro Luiz que pareceu ter se agradado com os aspectos realistas e verossímeis que faz da obra quase um documentário não só do contexto histórico, usado como matéria épica, mas também a linguagem. Vejamos o que disse o padre leitor:

É todo assim o livro. Diz a verdade sobre o roubo generalizado dentro da pátria. Verbera o latrocínio sorrateiro, mas quase coletivo. Empunha você o azorrague da indignação e vai distribuindo golpes a torto e a direito, sem piedade, especialmente para cima, onde estão os grandes e os patriotas.

Lê-se seu livro com agrado, de uma assentada, mesmo porque não é muito volumoso. Os versos são bem feitos, claros, diáfanos, e em geral de valor literário. Alguns, de muito valor literário. Meus parabéns. (LUIZ, 1954 In. FROTA, Aquino; MESQUITA, Oliveira; SPALDING, Walter, et al., ?).

Seguindo o mesmo espírito de Frota, em 1955, nove anos após a publicação da obra, Walter Spalding traz à tona o papel da sátira no contexto social e político. Vejamos o que ele escreveu sobre Os "Gatos" e o "Remédio":

A sátira foi, sempre, elemento de grande alcance social e político. Fernandes Barbosa, com OS GATOS E O REMÉDIO, satiriza a situação e os homens que transformaram o Brasil neste caos em que vivemos, com Lei Eleitoral feita de propósito para achincalhar, e outras coisas mais que infelicitam nossa terra (SPALDING, 1955. In. FROTA, Aquino; MESQUITA, Oliveira; SPALDING, Walter, et al., ?).

Esse aspecto satírico da obra também foi observado por Mildo Fenner que em sua resenha sobre a obra para o Jornal do Povo, em 1989, pontua que os aspectos históricos e políticos são de grande relevância para a compreensão de Os "Gatos" e o "Remédio" (1949), que, em suas palavras, tratam-se de "versos que, desde já, precisam ser entendidos à luz da época e dos fatos políticos e econômicos que marcaram o Brasil naquela época fértil em turbulências e atritos em muitas áreas" (FENNER, 1989). 
Após a leitura da obra e o levantamento da recepção crítica da obra podemos afirmar que Os "Gatos" e o "Remédio" (1949), de Fernandes Barbosa, é uma obra de epopeica qualidade literária. No entanto, no que diz respeito a sua classificação genérica, a priori, podemos classificala como uma obra híbrida, pois pode ser considerada como: um livro de poemas satíricos, composto majoritariamente por sonetos e, também, por sextilhas; mas pode ser lido como um longo poema que narra a história da nação durante a crise decorrente dos feitos políticos desde a época do Estado Novo e da Segunda Guerra Mundial.

Se levarmos em consideração à intenção do autor e a recepção da obra por alguns de seus leitores contemporâneos, - pessoas com grande afeição e estima e cujas leituras são pactuadas com o poeta de Cachoeira do Sul - RS, - inclinar-nos-emos a enquadrar a obra na primeira hipótese, ou seja, como um livro de poemas, dessa forma não será valorizado a narração da história que salta aos olhos do leitor diante da perplexidade e do extremo realismo crítico e satírico que ela apresenta.

Contudo, se considerarmos as discussões críticas teóricas contemporâneas, em torno do gênero épico, principalmente as desenvolvidas por membros do CIMEEP - Centro Internacional e Multidisciplinar de Estudos Épicos da UFS - não podemos ser indiferentes aos aspectos épicos fundamentais que podemos observar em Os "Gatos" e o "Remédio" (1949).

A guisa de introdução, podemos apontar alguns desses aspectos de forma sintética e que serão abordados no desenvolvimento do artigo, são eles: a obra se constitui como um longo relato com dupla instância de enunciação híbrida, a lírica e a narrativa, ou seja, ela pode ser lida como um longo poema narrativo com intenções de narras a Nação e os feitos dos políticos e do povo; nela percebe-se uma matéria épica elaborada literariamente; percebemos os principais planos estruturais de um poema épico que são o histórico, o mítico maravilhoso e o literário; identificamos o eu-lírico/narrador, o povo e o Honesto Pato, compondo o heroísmo coletivo da obra, ligados pelo signo da viagem, porém essa realizada no âmbito psicológico, e apegando-se ao pensamento crítico, sobre os problemas do país, à fé e a honestidade como as únicas formas de enfrentamento possível diante da tirania e do fascismo e trilhando a jornada heroica a fim de superar a crise política, econômica, moral e ética. 
A metodologia utilizada será a análise literária, entendendo o método de "análise" no âmbito das Ciências Humanas, e, mais especificamente, no sentido que é empregado nos estudos literários, tal como Moisés (2008), baseando-se em Prall (1967, p.45), ou seja, como um procedimento metodológico que produz explicação e interpretação. Isto é, analisar é uma forma de desmembrar as partes do todo e sondar a malha do conteúdo que lhes é implícita, começando a análise pela superfície visível, formada pela conexão das relações entre as unidades que a constroem, bem como a estrutura dos componentes da camada profunda, pesquisando a teia dos significantes e significados, de modo a oferecer dados seguros para a melhor avaliação e julgamento do texto (PRALL, 1967, p.45 apud MOISÉS, 2008, p. 14).

Ainda, na análise dos aspectos épicos seguiremos a proposta metodológica de Christina Ramalho (2013), que apresenta uma estratégia de leitura a partir da identificação e análise crítica dos principais aspectos épicos comuns ao Gênero Épico desde as primeiras manifestações épicas na antiguidade clássica até as formas épicas e híbridas produzidas na contemporaneidade. Sendo assim, acreditamos que a obra Os 'Gatos' e o remédio (1959), pode ser apresentado como uma dessas formas híbridas produzidas no século XX e que contribuem para refletir sobre o épico.

Sendo assim, cabe salientar que, não pretendemos provar que Os "Gatos" e o "Remédio" (1949) é uma epopeia ou um poema épico, mas nosso objetivo principal é expor, por meio da análise literária, os principais aspectos épicos observados na obra e que a coloca em diálogo com o Gênero épico. Vamos a eles.

\section{Os aspectos épicos em Os 'Gatos' e o remédio (1949)}

Os "Gatos" e o "Remédio" (1949) (1949), de Fernandes Barbosa 'pode ser considerado um livro de poemas, como intencionou seu autor, que apresenta os aspectos híbridos, já aqui salientado e que daremos ênfase na análise em questão, que são: a invocação, a proposição, a divisão em cantos, o plano histórico, o plano maravilhoso, o plano literário e o heroísmo épico.

\subsection{Sobre a divisão em cantos}

Em relação à divisão em cantos, o poema está organizado em uma "Tábua", que remete às leis mosaicas do Antigo Testamento, na Bíblia da tradição judaico-cristã, pondo em evidência 
a linguagem político-religiosa, e está dividido em duas partes, - que nos lembra o Antigo e Novo Testamentos das escrituras sagradas -, que o poeta nomeou como " 1 a Parte - os Gatos e o remédio" e "2a Parte - Conselhos ao Honesto Pato". Uma nomeação inventiva criativa² que tem a função híbrida - seja na narração episódica, seja na predominância temática.

Nesse sentido, ambas as partes estão estritamente ligadas e, na concepção do eu-lírico narrador, a ação dos personagens na primeira parte estão, de algum modo, relacionadas com a atuação dos personagens na segunda. Ou seja, na primeira temos a corrupção no cenário público da nação, na segunda teremos o discurso do corruptor no âmbito privado, tentando corromper o "Honesto Pato" por meio de conselhos políticos que representam a voz da experiência nos assuntos relacionados aos feitos e fatos da política da Nação brasileira. Nesse caso, o diálogo com o intertexto bíblico pode ser uma alusão crítica aos feitos anticristãos de personagens que, assim como Hitler, seus seguidores, e outros, assumiam-se cristãos, mas ignoravam as leis divinas, entre elas amar ao próximo como a ti mesmo, não matar, não roubar, etc.

As duas partes estão subdivididas poemas nomeados: a primeira, "1 a Parte - os Gatos e o remédio" , subdivide em oito poemas, seis sonetos e duas sextilhas, com títulos explicativos "Abra, general, os seus ouvidos" (p.4), "Poeminha com muita intenção" (p.5), "'Gato' gosta é de carícia" (p.6), "Ficaram raríssimas fontes"(p.7), "A voz de um fuzil” (p.8), "Quando será, meu Deus?" (p.9), "Origem da gataria" (p.10), "Oração dos pobres" (p.11); a segunda, "Parte 2 Conselhos ao Honesto Pato", divide-se em quinze sonetos que apresentam conselhos intitulados por algarismos romanos "I" (p.14), “II" (15), “III" (16), “IV" (17), "V" (18), "VI" (19), "VII" (20), "VIII" (21), "IX" (22), "X" (23), “XI" (24), "XII” (25), “XIII” (26), “XIV" (27), “XV" (28).

Pelo referencial numérico, e pelos referentes explícitos que fazem alusão ao envolvimento do Brasil nas guerras mundiais, identificamos uma ideia de "recuperação e recaída" dos países envolvidos nos conflitos internacionais, sobre os quais falam Gilbert (2016), principalmente quando ele diz:

Estimulada pela divisão entre o Oriente e Ocidente, a causa da unidade europeia ganhou força. Em 9 de maio, as indústrias de carvão francesas e alemãs e toda a produção de ferro e aço francesa foram colocados sob uma única autoridade. Em setembro, a União Europeia de Pagamentos foi criada, conectando quinze países europeus ao Reino Unido e à área esterlina, em um acordo de défcits e

${ }^{2}$ Categoria de Ramalho (2013). 
seperávits comerciais. Em 15 de junho, a Alemanha ocidental foi admitida no Conselho da Europa. De forma crescente, a recuperação econômica da Europa Ocidental se separava econômica e ideologicamente dos vizinhos do leste. (GILBERT, 2017, p.379 - grifo meu).

Observa-se a semelhança da ideia de divisão em dois, a ideia de "pagamento" após a Segunda - Guerra Mundial, e o simbolismo do número 15, referente aos países conectados e que receberiam esse "pagamento", e a data 15 de julho, de admissão da Alemanha ocidental no "Conselho da Europa". Assim, por meio de uma análise comparada entre o texto literário e intertexto histórico, poderá perceber, com mais ênfase, se há de fato uma relação crítica sugerida pelo poeta representada por meio dos conselhos ao "Honesto Pato", a fim de torna-lo um rico comerciante no cenário internacional.

No relato épico da "Parte 1- os Gatos e o remédio", o eu-lírico/narrador apresenta um panorama do que considera "a origem da gataria" - que ele presumi ter sido durante o Estado Novo - e a crise política e financeira causada pelos "gatos", pondo em evidência o agente político que teria poder para "frear" o roubo e a corrupção, e como agiam os corruptos desde os políticos até o mais ambicioso comerciante local. Propondo uma reflexão sobre a corrupção que vem "de cima" e contamina as camadas mais baixas das estruturas sociais, por causa da crise comercial e dos altos índices de inflação que, na obra, percebe-se e é relatada de forma crítica e crescente, identificado em dois poemas, "Poeminha com muita intenção" e "Origem da gataria". Vejamos abaixo o primeiro:

O preço dos artigos aumentando...

E cada dia o povo definhando

Até morrer com bicho nos pulmões.

E como terminar êsse calvário?

Comércio livre, sem intermediário,

Fuzilamento para os tubarões.

O apregoado tecido popular,

Gente pobre jamais poude comprar, Porque só tem pra turma dos milhões.

E como reprimir a bandalheira, Que campeia na terra brasileira?

Encostando à parede êsses ladrões.

O câmbio negro- negro para nós

Mas azul para os cabras que dão o bote -

Como um negrinho livre do chicote, 
Se apresenta risonho nos balcões...

Que fazer para que isso tenha fim?

É promulgar a lei do camboim,

Para cima de todos os ladrões.

(sic. FERNANDES BARBOSA, 1949, p.5 - grifo do autor original)

Observa-se que "Poeminha com muita intenção" é composto por duas sextilhas e uma septilha em decassílabos heroicos, forma poética tipicamente popular, cuja intenção é dar ênfase a voz que, mesmo aparentemente extremista e animada pela revolta, é solidária ao povo que sofre sendo vítima dos "tubarões", que representam os "pérfidos bandidos" ou "grandes comerciantes intermediários" ( FERNANDES BARBOSA, 1949, p.04,05,19).

Nesse poema, por meio da identificação do referente "Calvário", percebe-se uma aderência mítica do povo sendo sacrificado, que abordaremos com mais ênfase quando tratar do plano maravilhoso, e a voz do e-u-lírico / narrador, que representa o povo revoltado, chega ao extremismo de invocar "fuzilamento para os tubarões". A linguagem satírica do poema é forte e representa a "força de um fuzil", conforme em "Origem da gataria":

Os preços têm subido e vão subir;

Como foguetes em noite de São João,

Enquanto a lenha, de rijo, não cair,

Nas paletas de cada tubarão.

É de fazer de fato a gente rir,

A ingenuidade da nossa Comissão, Com Portarias querendo reprimir,

A desenfreada sanha de ladrão.

Os gatos se apossaram do Brasil, E somente com a força de um fuzil, Poderão se esquecer do Estado Novo,

Esse forno de falsa alvenaria, Donde proveio a faminta gataria, Para arrancar os olhos desse povo.

(FERNANDES BARBOSA, 1949, p. 10)

$\mathrm{Na}$ obra os Gatos representam os políticos corruptos que, segundo o eu-lírico, se "apossaram do Brasil". Observa-se que, na obra, todos os personagens são representados por animais e isso pode ser uma resposta ao discurso Adolf Hitler. Nesse sentido, Waldman (2009), ao falar sobre a linguagem do líder nazista, assim diz: 
Abre o primeiro volume uma epígrafe de autoria de Adolf Hitler: "Os judeus são indubitavelmente uma raça, mas eles não são humanos". Fazendo eco à epígrafe, a história será protagonizada por homens animalizados: ratos (judeus), gatos (nazistas), porcos (poloneses), cães (norte-americanos), sapo (francês), numa fábula às avessas, onde em vez de dar voz aos animais, o autor ressalta e identifica o animal nos humanos, situando um claro descompasso entre o tipo de história apresentada e seu veículo - os quadrinhos, inaugurando um terreno novo e controverso no que concerne à representação da Shoá (WALDMAN, 2009, p.318).

Na primeira parte do poema, percebemos nitidamente essa animalização dos homens em um cenário mais amplo, de forma mais pública. Como se revelasse, na voz crítica e revoltada do eu-lírico, a corrupção, o roubo e o discurso das armas no cenário nacional. Num país onde os seres humanos parecem ser guiados por seus instintos animalescos. Assim, o poeta, por meio da representação, utiliza a própria linguagem de Hitler não somente para criticar a atuação de políticos nazistas corruptos, que representam os "Gatos", e a corrupção de forma mais geral, indo além da "crítica a partidos".

Enquanto a voz do eu lírico / narrador vai relatando o cenário brasileiro dominado pelos gatos, pela corrupção e roubo generalizado, sobressai com força a voz de revolta que parece ver como única solução o uso das armas para resolver o problema nacional, e por isso exige a atitude do General. Mesmo ouvindo a voz de um fuzil, o poeta pretende manter a crença na regeneração dos gatos, conforme ele finaliza com os últimos versos dessa parte intitulado "Orações dos Pobres" que ele parece se resignar de sua condição humana que, por revolta, busca a solução na violência e voltar-se para o divino, conforme vimos na invocação cristã.

A ideia de regeneração, no âmbito da política internacional, e tomando por metonímia "gato" / nazistas / Partido Nazista / Alemanha, remete-os ao que explica Gilbert (2013), quando fala da regeneração da Alemanha Ocidental no período pós-guerra, ou seja:

A Alemanha Ocidental não fazia parte do Tratado do Atlântico Norte, mas sua regeneração no pós-guerra estava de acordo com os ideais democráticos do ocidente que sustentavam o conceito de existência da OTAN ${ }^{3}$. Em 23 de maio, a República Federal da Alemanha - também conhecida como Alemanha Ocidental - passou a existir oficialmente, com capital em Bonn, no Reno. Em 12 de setembro, depois das eleições disputadas livremente, Theodor Heuss foi eleito presidente, e Konrad Adenauer, chanceler. Nenhum dos dois tinham feito parte do Partido Nazista. Ambos tinham se oposto aos excessos do regime de Hitler.

${ }^{3}$ OTAN - Organização do Tratado Atlântico do Norte 
Adenauer tinha sido demitido como presidente do Conselho de Estado prussiano por sua oposição ao nazismo e preso duas vezes- em 1934 e 1944. (GILBERT, 2017, p.370-371).

Como democrata, o Fernandes Barbosa parecia favorável à regeneração dos países envolvidos nas guerras mundiais, e embora a Alemanha Ocidental não fazia parte dos doze países ${ }^{4}$ da que aderiram ao Tratado do Atlântico Norte, a voz do eu-lírico / narrador parece defender que ela seja incluída nesse processo de regeneração, afinal foi o Partido Nazista da Alemanha Ocidental que deu início às guerras mundiais.

Nesse sentido, observa-se que ler os poemas de forma isolada não seria a melhor forma de interpretar a obra, pois não irá perceber a mudança da voz que invoca as armas e, quase se redime, ao invocar o divino e pedir a regeneração dos corruptos, revelando assim as marcas da ironia e que, embora o poeta use o discurso de invocar as armas, ele o faz como uma representação realista da linguagem da época e defendendo a mudança de atitude na linguagem e, principalmente, na atuação sócio-política dos personagens envolvidos. Pois só assim será possível alcançar a face sublime e divina do herói honesto, incorruptível e que abre mão da violência, como quem abandona as armas, conforme veremos no poema "Oração dos pobres" (p.11), quando tratarmos da invocação.

$\mathrm{Na}$ "2a Parte - Conselhos ao Honesto Pato", o relato épico está centrado na voz do eu lírico narrador que tenta, a partir de conselhos, transformar o Honesto Pato em um Ratão, caso se corrompa, ou até um Gatão, caso se envolva na Guerra, ou aceite fazer contratos com om corruptos internacionais, e se torne um corrupto estrangeiro e reproduza o sistema de corrupção. Nesses conselhos, percebe-se o mesmo cenário de crise financeira crescente representado nos poemas da primeira parte, será possível identificar no desenvolvimento lírico-satírico dos conselhos irônicos e que abordaremos com mais ênfase quando tratarmos do plano histórico.

Em suma, a divisão em cantos contextualiza com dois períodos críticos do Brasil, a chegada da crise no Brasil, em 1930-1931, e o momento crítico da pós-guerra, partir de 1943. Mas

\footnotetext{
${ }^{4}$ Segundo Gilbert (2017), os doze países que aderiramąa Tratado Atlântico do Norte foram: "os Estados Unidos, Canadá, reino Unido, França, Luxemburgo, Bélgica, Holanda, Itália, Portugal, Dinamarca, Islândia e Noruega" (GILBERT, 2017, p.370).
} 
também, mostra o cenário do roubo e da corrupção no âmbito internacional e nacional, nacional e local, público e privado.

\subsection{Sobre a invocação}

Em relação à invocação épica, percebe-se duas invocações em que o eu-lírico narrador invoca a dois destinatários distintos: uma trata-se de uma invocação a um destinatário pátrio ${ }^{5}$, outra uma invocação cristã ${ }^{6}$ ao "Senhor". Tratam-se de dois destinatários superiores ao poeta e ao povo e que revela a incapacidade do eu-lírico/narrador de solucionar os problemas, ou seja, pede ajuda para resolver os problemas da nação. Com isso, o poeta estabelece um diálogo direto com a tradição épica clássica, pois os poetas, quando utilizavam o recurso da invocação, fazia-o para invocar as musas a fim de obter ajuda para composição da epopeia ou do poema épico, tal como explica Ramalho (2013) quando diz que

Na epopeia, a invocação constitui, tradicionalmente, um recurso de efeito retórico relacionado a uma pretensa disparidade entre a dimensão do texto que vai ser escrito e o fôlego do (a) poeta (isa) para realizá-lo. Assim, invocando a musa, registra o(a) poeta(isa) seu pedido de inspiração, amparo, energia e clareza, para que o resultado seja adequado à matéria épica enfocada (RAMALHO, 2013, p. 62).

Parece que o que serve de fôlego ao eu-lírico narrador não é a voz das musas, mas a voz do discurso político - religioso que inspira poesia e também tenta "inspirar" à corrupção do cidadão honesto, conforme observa nos conselhos ao Pato.

Sobre as invocações, a primeira o poeta nomeou como "Abra, General, os seus ouvidos...", e, por não está explicitado no corpo do poema referência há um general específico, acredita-se que se trata de uma linguagem metonímica, em que o poeta toma uma parte para se referir ao todo, ou seja, General para se referi às Forças Armadas, que muitos brasileiros acreditam, ser uma das instituições responsáveis por manter a ordem nacional, em momentos críticos e extremos. Vejamos os versos abaixo:

Abra bem, General, os seus ouvidos, Para escutar as almas torturadas, Que cruzam, por aí, esfarrapada, $\mathrm{Na}$ tristeza de todos os gemidos!

${ }^{5}$ Conforme as categorias de Ramalho (2013).

${ }^{6} 6$ Conforme as categorias de Ramalho (2013). 
Arme-se da justiça das espadas

E mande seus soldados aguerridos, Decapitar, ao longo das calçadas, Os tubarões, os pérfidos bandidos.

Persiga e mate toda essa canalha, A corja miserável que atrapalha, De nossa Pátria a marcha ascensional.

Na Câmara se alguém gritar - não pode!

Mande o líder catar barbas de bode, Fechando essa masorca nacional.

(FERNANDES BARBOSA, 1949, p. 04)

O eu-lírico narrador invoca o General em favor das "almas torturadas", como se o poema fosse escrito a partir dessas vozes. elo ano de publicação da obra, é possível que esse general seja o militar Eurico Gaspar Dutra (1873 - 1974), pois esse, de 1946 a 1951, foi o décimo sexto presidente do Brasil, eleito pelo voto popular, e entre 1936 a 1945 foi ministro de Guerra. Ele foi também, após receber o apoio popular nas urnas, um dos responsáveis pelo fim da ditadura do Estado Novo, que pode ser a "masorca nacional" a qual o eu-lírico/narrador se refere, um lugar de bagunça, desordem, intentonas, agitação, perturbação da ordem, anarquia, etc.

A segunda invocação, o poeta nomeou de "Oração dos Pobres". Nela percebe-se uma mudança de comportamento e o eu-lírico narrador que ao invés de invocar a força humana invoca ao Senhor, pedindo que ele conduza os políticos corruptos à regeneração. Vejamos abaixo:

VÓS que governais as terras e os oceanos, Fazendo do mundo um brinquedo na mão, Guiai, Senhor, os gatunos desumanos, Pelo caminho da regeneração.

Fazei com que a nossa carne e o nosso pão, Venham das mãos avarentas dos ciganos, Com o peso exato, sem alteração, Às mãos dos que sofrem tantos desenganos!

Convencei, Senhor, que o negociante deve, Trazer ao pescoço, presa como um breve, Essa Tabela que a vista Ihe sombreia

Para evitar que a sua bárbara miopia Baralhe os preços, em plena luz do dia, 
E o leve, por engano, à Rua da Cadeia.

(FERNANDES BARBOSA,1949, p. 11 - destaque e grifo feitos pelo poeta)

Conforme foi mostrado, quanto ao conteúdo, ambas invocações são convocatórias: na primeira, invoca a Pátria, ao General para que ele ouça as vozes do povo, das almas torturadas; na segunda, invoca Deus em prol da regeneração dos Gatos e da conscientização dos negociantes corruptos para que mudem de comportamento e sejam justos em relação ao preço dos produtos que negociam, para que não sejam levados à "Rua da Cadeia".

Esse comportamento de invocar ao General e a Deus, remete que Ramalho (2013) diz em relação as figuras invocadas pelos poetas

Com o advento do Cristianismo, a invocação a figuras da mitologia pagã ou foi rechaçada ou utilizada apenas para enfatizar o aspecto retórico e épico do "chamamento". O destinatário da invocação passou a ser Deus e/ou as figuras relacionadas à religiosidade cristã. Outro procedimento passou, no entanto, a ser comum: a dupla invocação - à musa e a Deus -, cabendo à primeira a cumprir uma função decorativa, relacionada à tradição épica, e, ao segundo, ser, de fato, o sustentáculo moral e religioso do canto (RAMALHO, 2013, p.62).

Sendo assim, parece que em Os 'Gatos' e o remédio (1949) o General assume o lugar das musas na invocação, que, de algum modo, recorda Getúlio Vargas, que fora considerado "pai dos pobres" e "mãe dos ricos". Logo, observa a mesma identificação do feminino e da força militar associado à direita.

Ainda em relação à invocação, podemos interpretá-las no âmbito internacional, considerando que as duas invocações ou chamamentos (ei), ao "General" e ao "Senhor" podem ser referências, ou pistas, para indicar ao leitor um único destinatário pátrio, que poderia ser o general Eisenhower (1890-1969), que atuou como general de cinco estrelas no Exército Americano e foi comandante supremo das Forças Aliadas durante a Segunda Guerra Mundial. Sendo assim, a voz do eu-lírico /narrador, invoca diretamente àquele que atuava diretamente nos conflitos armados e que, mais tarde, em 1951, veio ser presidente da OTAN.

Contextualizando com a referência do eu-lírico / narrador, a um governo ideal que poderia ser eleito, de fato, e que deixaria de "alisar pelo de gato" (FERNANDES BARBOSA, 1949, p.9), corrobora com as possíveis interpretações do destinatário ser: no âmbito nacional, o general

${ }^{7}$ Conforme as categorias de Ramalho (2013). 
Dutra como aquele que seria eleito no Brasil, e colocaria um fim na Ditadura do Estado Novo, recordando o Golpe de 30 chefiados por Getúlio Vargas; no âmbito internacional, o general Dwight David Eisenhower, pois, posteriormente, ele foi principal opositor do Partido Nazista, e um dos responsáveis em pôr fim aos conflitos bélicos.

Nesse sentido, Gilbert (2017) dá um panorama da importância do general Eisenhower no contexto internacional, o cansaço generalizado como um trauma causado pelas guerras, e o desejo do fim desses conflitos:

Nos Estados Unidos, a questão da guerra na Coreia foi o centro da campanha eleitoral durante o outono. $O$ candidato republicano foi o general Eisenhower, que, lançando mão de toda sua autoridade como soldado - e, até abril, como o supremo comandante da OTAN-, se utilizou da fadiga generalizada em relação à guerra para condenar Truman pela maneira como lidara com o assunto e para identificar o conflito como "guerra de Truman". Em uma transmissão televisa nacional em 24 de outubro, Eisenhower descreveu a Coreia como "o cemitério de 20 mil americanos mortos" e prometeu que, se fosse eleito presidente, poria fim à guerra. (GILBERT, 2017, p.400).

Sendo assim, o fato de considerar o general Eisenhower como possível destinatário pátrio não anula ou invalida a invocação cristão, pois podemos interpretar o primeiro destinatário dessa segunda invocação na dimensão explícita do discurso lírico como Deus, em sentindo universal, e na dimensão explícita do discurso lírico o general Eisenhower. Dessa forma, a invocação admite que Deus fica em primeiro plano e o destinatário humano em segundo.

Com a necessidade de uma segunda invocação, que pode ter duplo sentido, a Deus e aos homens, podemos dizer que a primeira invocação ao general Dutra perde um pouco de força e assume um papel decorativo ou representativo daqueles que, deixados levar pelo primeiro impulso, invocam as forças militares e as armas. Nesse sentido, percebe-se a ideia filosófica e religiosa de cunho moral e didático que mostra, por meio da representação literária, que em momentos de crises devemos invocar em primeiro lugar a Deus e em segundo lugar aos homens, apelando para a fé e para a regeneração. 


\subsection{Sobre a proposição}

Em relação à proposição em Os "Gatos" e o "Remédio" (1949), percebe-se duas obedecendo a divisão em cantos: a primeira, dispersa e multifragmentada ${ }^{8}$; e a segunda, nomeada ${ }^{9}$ como "apresentação", destacada no início do poema.

$\mathrm{Na}$ “1 a Parte - os Gatos e o remédio" a proposição é apresentada de forma dispersa e tem múltiplos desdobramentos em vários poemas, que dão um panorama geral da matéria épica que será tratada, são eles: "Poeminha com muita intenção"(p.05), em que ele apresenta o cenário brasileiro dominado pelos gatos, pela crise financeira, pelo roubo e pela corrupção; "Gato gosta é de carícia..." (p. 06), que ele apresenta a barbaridade daqueles que detêm o poder e apresenta a frieza da violência da Gestapo, polícia secreta da Alemanha Nazista de Hitler, cuja história é associada à torturas psicológicas no "jogo de Gato e Rato", que será aplicado ao "Pato" na segunda parte da obra; "Fiaram raríssimas fontes..."(p.07), em que ele apresenta o jornal como raríssimas fontes de onde ele bebe as notícias para composição literária; "A voz de um fuzil"(p.08), onde ele apresenta a meditação do eu-lírico / narrador, e propõe uma literatura pensante sobre os problemas do país; “Origem da Gataria”(p.10), em que ele propõe que os Gatos se apossaram do Brasil durante o Estado Novo. No que diz respeito ao centramento temático, trata-se, portanto, de proposições que tem enfoque no plano histórico ${ }^{10}$, cujos conteúdos fazem referências à história do Brasil, pós Estado Novo, e após as guerras mundiais, permitindo a contextualização com os conflitos internacionais e seus reflexos na história da nação.

$\mathrm{Na}$ "2a Parte - Conselhos ao Honesto Pato", a proposição consiste em um texto metalinguístico e filosófico feito pelo próprio poeta, e é nomeada11 como "apresentação", conforme cito abaixo:

APRESENTAÇÃO

- Quem é o Honesto Pato?

- HONESTO PATO é todo aquele que se preocupa com o estado de miséria do povo brasileiro.

É o cidadão que, apesar de explorado, não explora, apezar de roubado, não rouba, e que, em matéria de política, vota por idealismo, por conviç̧ão, jamais mudando de partido por conveniência pessoal, coisa tão comum nesta época de

${ }^{8}$ Conforme as categorias de Ramalho (2013).

${ }^{9}$ Conforme as categorias de Ramalho (2013).

${ }^{10}$ Conforme as categorias de Ramalho (2013).

${ }^{11}$ Conforme as categorias de Ramalho (2013). 
oportunismo e de falta de vergonha, principalmente entre a casta dos políticos profissionais... os eternos salvadores da Pátria. (sic. FERNANDES BARBOSA, 1949, p.13 - grifo do autor original).

Nesse texto de apresentação Fernandes Barbosa apresenta não apenas uma explicação filosófica e moral sobre a identidade do "Honesto Pato", mas também deixa registrado seu ponto de vista e sua crença sobre o verdadeiro ato heroico diante de um cenário de roubo, corrupção e violência. Deixando entender, nas entre linhas do dito e não dito, que a voz do eu-lírico / narrador, embora esteja em primeira pessoa, não se trata dele mesmo, mas de uma representação identitária que será incorporada e manifesta com extremo realismo, e sob a face do extremismo, nos conselhos dados ao Honesto Pato, representando a voz do tentador.

\subsection{Sobre o plano histórico}

Para a elaboração do plano histórico o poeta se apropria de fatos e acontecimentos históricos referentes às guerras mundiais, a ameaça iminente de conflitos bélicos posteriores como a Guerra da Coreia (1950-1953) no contexto da Guerra fria (1947-1991), e a crise financeira, política e moral nesse período marcado por guerras e, no cenário nacional, um período marcado pelas crises instaurada desde o Estado novo e que ainda não havia sido superado, criando um ambiente ficcional muito semelhante ao mundo real, tão semelhante que chega a causar certo estranhamento no leitor que pode se questionar se o texto escrito se trata de ficção ou de uma escrita da história.

$\mathrm{Na}$ obra, no que diz respeito às fontes, percebe-se que predomina as fontes explicitamente referenciadas ${ }^{12}$, ou seja, identifica-se as referências às guerras mundiais, à crise do café, á crise do Estado Novo, à atuação da Gestapo - polícia secreta da Alemanha Nazista de Hitler, ao PTB - Partido Trabalhista Brasileiro, à União Soviética, aos Russos, Stalinismo - regime político da União Soviética de Stalin, entre outras. No entanto identifica-se referentes não explícitos, geralmente podendo ser associados à acontecimentos históricos no âmbito internacional. Vejamos abaixo, exemplo de fontes explicitamente referenciadas que compõem, de forma fragmentada, o plano histórico do poema:

\footnotetext{
12 Conforme categorias de Ramalho (2013).
} 
Segue o exemplo daquele petebista,

Que em sordidez tem panos para manga

E na difícil arte de golpista

Trabalha e larga o próximo de tanga.

No sorriso nipônico e budista

Traze, como no fundo de uma sanga,

A imensa falsidade stalinista,

Que faz do povo um manso boi de canga.

Do partido que for majoritário,

Ponhas logo teu nome no fichário,

Desprezando o pessoal da oposição.

De homens como Borghi te aproxima

E olhando o panorama lá de cima,

Embriaga-te nas nuvens de algodão.

(sic. FERNANDES BARBOSA, 1949, p. 16 - grifo do poeta)

Vejamos agora, exemplo de fontes explicitamente não referenciadas que ajudam a compor, o plano histórico do poema:

Como esquadrilha russa de aviões,

Dizem que os gafanhotos já chegaram,

Devorando as imensas plantações,

Que mãos abençoadíssimas plantaram.

Mas existe uma verba de milhões,

Que os nossos governantes decretaram,

Destinadas ao combate dos saltões,

Que em forma de ovóide para traz ficaram.

Mete os peitos, Honesto, resoluto,

E banca um japonês bárbaro e bruto,

Nesse combate que se vai travar.

Aplica a verba toda nessa guerra

E espera o vento bom que vem da serra,

Para atira-los, um dia, para o mar!

(sic. FERNANDES BARBOSA, 1949, p.20)

Esse tipo de identificação direta da realidade no texto ficcional é muito comum em obras literárias extremamente realistas, como é o caso de Os "Gatos" e o "remédio" que tratam de problemas contemporâneos ao autor, de forma violenta e, até fascista, tal como é a realidade que o poeta ambiciona criar e, de certa forma, acaba criando. É um plano histórico que vai sendo 
narrado de forma fragmentada ${ }^{13}$, onde a história é contada a partir de fragmentos identificáveis seja na revolta na voz do eu-lírico / narrador na "1 a Parte - os Gatos e o remédio" e nos conselhos na "2a Parte - Conselhos ao Honesto Pato".

\subsection{Sobre o plano maravilhoso}

Em relação às fontes das imagens míticas usadas na elaboração do plano maravilhoso de Os "Gatos" e o "remédio" (1949), observa-se que correspondem à fontes míticas híbridas"14, sendo construído a partir da hibridização de imagens míticas do simbolismo animal, enraizadas na cultura popular, constituindo-se como fontes míticas tradicionalmente ${ }^{15}$ usadas para explicar determinado comportamento humano, e de referenciais mítico - simbólicos da tradição judaicocristã. Representando a luta do bem, a partir da busca pelo maravilhoso religioso, contra os feitos malignos de personagens que se comportam como animais.

Assim, temos a aderência mítica no plano maravilhoso: dos gatos - que representam os políticos corruptos estrangeiros que se apossaram do Brasil, e que parece ser amigo do Pato; os Ratos - que representam os políticos corruptos brasileiros, e que pode ser devorados pelos Gatos; o Pato - representa o cidadão honesto, político honesto que se preocupa com o estado de miséria dos pobres; os tubarões - representam os grandes empresários envolvidos com corrupção; os cabras - representam os pequenos comerciantes também corruptos, que tem pouca visão, mas que se acham espertos; ovelha - representa o povo enganado pelos comerciantes.

Pela teoria de O Simbolismo Animal, conforme explica Jean Paul Ronecker (1997), temos as seguintes explicações para as imagens dos animais incorporados na aderência mítica no texto, principalmente na "1 $\underline{a}$ Parte - os Gatos e o remédio", embora sejam retomados também na"2a Parte - Conselhos ao Honesto Pato", são elas: o gato tem sua imagem associada ao outro mundo, ou seja, é a fortaleza de outro mundo (RONECKER, 1997, p.323), daí entendemos porque, no poema, ele representa o estrangeiro, aquele que veio de fora e se apossou do Brasil; o rato tem sua imagem associada a "uma criatura noturna e perigosa" simbolizando "o roubo, o ladrão" (RONECKER, 1997,p.348); os tubarões simbolizam um terrível predador do mar temido pelos

${ }^{13}$ Conforme as categorias de Ramalho (2013).

${ }^{14}$ Conforme as categorias de Ramalho (2013).

${ }^{15}$ Conforme as categorias de Ramalho (2013). 
pequenos animais marítimos (RONECKER, 1997, p.205), ou seja, é um peixe grande que devora peixe pequeno, no texto literário, representa os grandes empresários envolvidos em corrupção que irá devorar pequenos comerciantes; as cabras, feminino de bode, simbolizam a "mãe nutriz", da "iniciadora", e "da grande provedora", no texto podem estar associados à burguesia; ovelha, simboliza a fronteira entre o mundo dos vivos e além (RONECKER, 1997, p.284),

Em relação ao Pato, que é o personagem central na "2a Parte - Conselhos ao Honesto Pato", segundo Ronecker (1997), ele representa "um enganado", e geralmente sua imagem está relacionada a um casal, o pai e a mãe, simbolizando a união e felicidade conjugal (RONECKER, 1997, p.156). Daí, talvez, a justificativa para as duas invocações, a primeira associada ao general, que assume o lugar das musas, e a de Deus que representa a imagem sagrada de "Deus - Pai".

Enfim, é o humano tratado como animal no mundo selvagem, onde há a presa e há o predador e um sempre pode acabar sendo devorado pelo outro. Assim sendo, a aderência mítica da tradição judaico-cristã irá funcionar como uma forma de vencer os feitos animalescos e aproximar o homem de Deus.

\subsection{Sobre o plano literário}

Na elaboração do plano literário o poeta se apropria de uma linguagem intertextual com a História, fazendo referências diretas a ela e questionando e problematizando questões bastante problemáticas que acabam sendo incorporadas na ficção que acaba trazendo muitos elementos da realidade e acaba sendo um discurso da própria História e para entender só lendo, de forma interdisciplinar e à luz dos fatos históricos.

Ainda em relação ao uso da linguagem, percebe-se que predomina a linguagem líricosimbólica ${ }^{16}$. O poeta se apropria de referentes míticos simbólicos para explicar os personagens e para isso utiliza diversos recursos de linguagem lírica, tais como: comparações, metáforas, metonímias, ironias.

Exemplos de comparações no texto são: "Como um velho caboclo a matutar" (p. 08), "tangendo esse povo como ovelha"(p.08), "De homens como Borghi te aproximas"(p. 16), "Como aquele Fouché do tempo antigo"(p.17), "Chegaram como simples imigrantes" (p.19), "Pelado

\footnotetext{
${ }^{16}$ Conforme as categorias de Ramalho (2013).
} 
como filho de ratão/ mas esperto, talvez, como jaguar"(p. 21), "Quem reflete assim como espelho" (p. 27), "Do que subir na vida como Gato" (p. 28). Essa linguagem comparativa, que o poeta utiliza, contribui para a construção da identidade dos personagens, principalmente do herói, que exploraremos mais adiante, e os outras personagens que são os vilões responsáveis pela infelicidade do herói, do povo, do Pato.

São exemplos de metáforas no texto: “Fuzilamento para os tubarões"(p. 05), "Gato só gosta é de carícia"(p.06), "Livrar o povo dos chacais" (p. 07), "Os gatos se apossaram do Brasil” (p.07), "Enquanto os Gatos pulam para a frente / O Pato, à retaguarda, vai ficando" (p. 18), “Todo mundo conhece os tubarões" (p. 19), "Torna-te negociante, amigo PATO"(p. 19), "Dizem que os gafanhotos já chegaram" (p. 20), "Enquanto o Pato vive na pobreza” (p. 21), “O Estado Novo, meu Honesto Pato"(p.22), "Se tiveres, meu Pato, um pistolão" (p. 25), "Para fazer-te um Gato refinado" (p. 26), "- Brasil que estava aqui, Gato comeu!”(p.28). Essa linguagem metafórica é uma comparação que é incorporada de forma mais direta e cria um sentido mais ficcional para o texto, cria uma linguagem mais simbólica e mais hermenêutica, tal como um código que precisa ser traduzido, interpretado.

Identifica-se o uso recorrentes de pronomes de tratamento e possessivos para aproximar o eu-lírico narrador do herói, e distanciar do discurso das armas e da corrupção, mesmo quando é proferido por ele. Exemplos de pronomes de possessivos são: "seus ouvidos"(p.04), "interrogo meus botões"(p. 08), "Diante dos meus olhos cismarentos" (p. 08), "Quando será, meu Deus"(p.09) “Nossa comissão"(p. 10), "nossa carne, nosso pão"(p. 11), "A gente finge que não tem memória” (p. 24), “Pois tenho fé em meu Honesto Pato"(p. 28).

Além dos pronomes possessivos, percebe-se o uso recorrente de pronomes demonstrativos, que demonstram a realidade de forma quase documental, referente à história ou ao caráter e atuação de algum personagem, como por exemplo: "essa masorca nacional"(p. 04) "esses ladrões" (p.05), "E como terminar esse calvário"(p. 05), “Que fazer para que isso tenha fim"(p. 05), "tangendo esse povo como ovelha" (p. 08), "deste povo"(p.10), "Joga fora esse espírito de luta"(p. 15), "Peregrina através desses partidos"(p.15), "Segue o exemplo daquele petebista" (p. 16). 
Percebe-se ainda, o uso de pronomes pessoais, usador para se incluir no tecido popular, como parte do povo, ou para mostrar sua relação pessoal com Deus, vejamos os exemplos quando diz: "Câmbio negro - negro para nós" (p.05), "Se eu tivesse poder e autoridade" (p.06), "VÓS, que governais as terras e os oceanos" (p. 11).

Em suma, percebe-se, por exemplo nos versos citados acima, que se trata de uma linguagem híbrida lírica-simbólica que mistura o político e o religioso. Assim sendo, no tocante ao reconhecimento do lugar da fala autoral, a voz do eu-lírico / narrador é engajada ${ }^{17}$ e representa a linguagem de crise, lembrando a linguagem do maneirismo. Aspecto esse que deve ser analisado com mais ênfase em estudos posteriores.

\subsection{Sobre o heroísmo épico}

O herói de Os "Gatos" e o "remédio" é o "Honesto Pato", que tem sua honestidade provada durante a "2a Parte - Conselhos ao Honesto Pato", e ele é explicado, nas palavras do poeta na proposição que introduz essa parte, conforme vimos anteriormente, ou seja é "é todo aquele que se preocupa com o estado de miséria do povo brasileiro. [...]. (FERNANDES BARBOSA, 1949, p.13). Ou seja, trata-se de um herói coletivo ${ }^{18}$, que engloba, inclusive o poeta, pois a realização literária dessa obra já põe em evidência tal preocupação.

Trata-se de um herói híbrido com suas fraquezas, mas também com virtudes como a fé e a crença para vencer o cenário de crise, corrupção e violência. Ele que age nesses dois planos, histórico e mítico, e que tem um enfrentamento humano existencial diante do discurso fascista que ora parece exaltar as armas, a violência, mas que é vencido pela redenção do povo e do eulírico / narrador que optam pela mudança do comportamento e discurso fascista e pela busca do caminho da fé e da oração, conforme vimos no poema "Oração dos Pobres", quando falamos sobre a invocação.

Quanto ao percurso do herói, ele transita do plano histórico para o maravilhoso ${ }^{19}$. Ou seja, a viagem do herói se dá no âmbito psicológico, no processo de reflexão sobre a realidade histórica do país, iniciando no interior do eu-lírico, nas "horas" que ele passa matutando com seus botões,

${ }^{17}$ Conforme as categorias de Ramalho (2013).

${ }^{18}$ Conforme as categorias de Ramalho (2013).

${ }^{19}$ Conforme as categorias de Ramalho (2013). 
como em "A voz de um fuzil", escrito em sextilhas, representando o processo reflexivo do povo que ocupa a infraestrutura do país e sente-se oprimido e sufocado por aqueles corruptos que ocupam e dominam as estruturas sociais, não só no âmbito da política, mas também da polícia, por exemplo, que, corrompida e aliada aos políticos corruptos, tentará demolir à superestrutura do Estado, da Nação, e do texto literário.

Logo, o herói coletivo é um sujeito histórico que, por meio da comparação, representa "um velho caboclo", isto é, pode ser qualquer um do povo que se preocupa com a "miséria do país". Vejamos abaixo, o "A voz de um fuzil", que comparando com a proposição da "2a Parte Conselhos ao honesto Pato", revela de forma sutil que o próprio eu-lírico / narrador pode ser o "Pato", pois tanto o "velho caboclo" como o "Pato" representam aquele que se preocupa com a miséria do país:

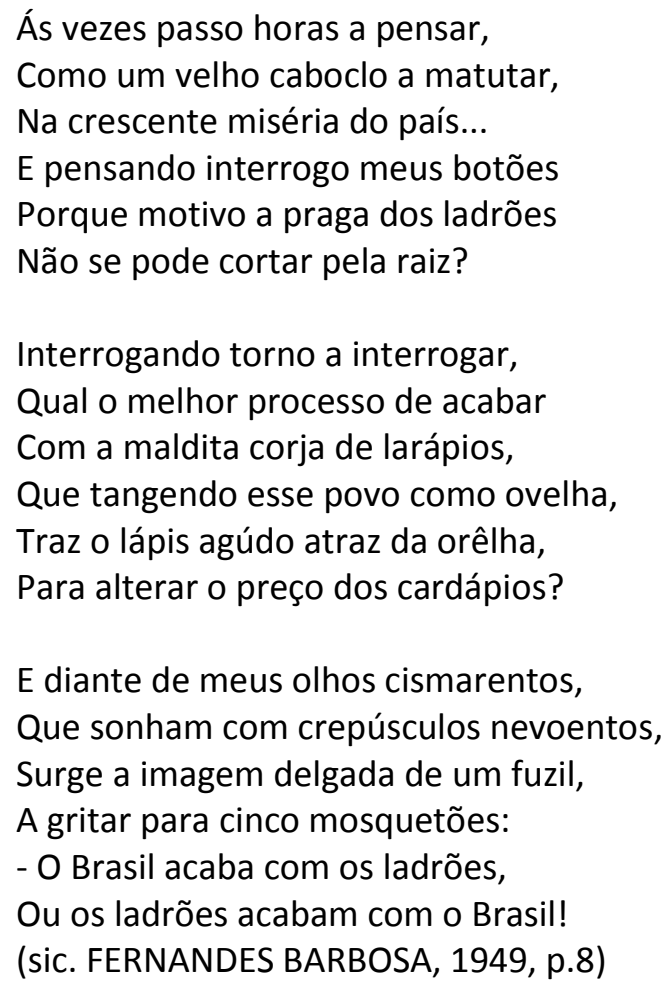

A aderência mítica ocorre com a associação do povo com a "ovelha", que no campo referencial simbólico tem sentido semelhante ao "cordeiro", por ser da mesma família, porém, a ovelha é a mãe do cordeiro. Por metonímia, o povo associado a esse referente simbólico remete Jesus, o Cordeiro sacrificial, ofertado por Deus como sacrifício pacífico pelos pecados da humanidade. 
Nesse sentido, o povo já havia sido associado à Cristo pelo referente do "Calvário", em poeminha com muita intenção, já citado anteriormente. Corroborando para a aderência mítica de Jesus Cristo na identidade do povo. Ou seja, assim como o Messias foi crucificado e enfrentou seu calvário, vencendo a morte, assim também o povo seguia definhando para o calvário.

$\mathrm{Na}$ "2a Parte - Conselhos ao Honesto Pato", o poeta consagra o "Pato" como herói, pois resiste aos conselhos da voz do eu-lírico/narrador que representa a voz do tentador e lembra, inclusive, quando Jesus enfrentou a tentação no deserto, quando a serpente, um arquétipo de Satanás, mostrou-lhe a glória do mundo. Segundo o texto sagrado, Cristo usou a palavra para vencer as investidas do mal. Em Os "Gatos" e o "remédio" (1949), o Pato passa silenciado por toda sua jornada, ignorando os conselhos tentadores da voz que deseja corromper. Percebe-se que a identidade do "Pato", que já sabemos que é alguém que "se preocupa com o estado de miséria do povo brasileiro...", será definida, também, pelos conselhos. Vejamos abaixo, alguns para meio de exemplificação:

Tabela 1: Análise dos conselhos ao "Pato"

\begin{tabular}{|c|c|}
\hline Alguns Conselhos & Logo: Identidade do Pato é... \\
\hline $\begin{array}{l}\text { É aconselhado a seguir o movimento da turma corruptos, e se transformar } \\
\text { em um Rato, político corrupto brasileiro, pois só assim terá maior } \\
\text { merecimento aos olhos do corrupto (p. 14) }\end{array}$ & $\begin{array}{l}\text { - Não faz parte da turma dos } \\
\text { corruptos } \\
\text { - Não é um Rato } \\
\text { - Não têm tanto merecimento na } \\
\text { visão dos corruptos }\end{array}$ \\
\hline $\begin{array}{l}\text { É aconselhado a jogar fora o espírito de luta que o destina ao } \\
\text { esquecimento, a ouvir enquanto o chefe fala, peregrinar pelos partidos } \\
\text { (p.15) }\end{array}$ & $\begin{array}{l}\text { - Tem um espírito de luta } \\
\text { - É silenciado } \\
\text { - É partidário }\end{array}$ \\
\hline $\begin{array}{l}\text { É aconselhado a se aproximar e seguir o exemplo de políticos corruptos, } \\
\text { como Hugo Borgi, por exemplo (p. 16) }\end{array}$ & - É tentado à corrupção \\
\hline $\begin{array}{l}\text { É induzido a transformar-se num cabotino, num bajulador, a desembuchar, } \\
\text { e entrar no Cordão dos puxa, ou seja, na expressão popular ser um puxa- } \\
\text { saco e ser cherêta, entregar os companheiros ( } p .17)\end{array}$ & $\begin{array}{l}\text { - Não desembucha } \\
\text { - Não é puxa-saco } \\
\text { - Não é bajulador } \\
\text { - Não é cherêta }\end{array}$ \\
\hline $\begin{array}{l}\text { É induzido a topar o contrabando, e a não querer gente pronta no seu } \\
\text { bando, ou seja, só pessoa que esteja disposta a contrabandear, pois a } \\
\text { polícia deixa passar o contrabando (p. 18) }\end{array}$ & $\begin{array}{l}\text { - Parece não fazer parte do } \\
\text { contrabando }\end{array}$ \\
\hline É induzido a seguir o exemplo de negociantes desonestos (p.19) & - Não é um negociante desonesto \\
\hline $\begin{array}{l}\text { É aconselhado a se envolver no combate e pegar o dinheiro, a verba de } \\
\text { milhões do Governo, e aplicar na guerra ( } p .20)\end{array}$ & $\begin{array}{l}\text { - É alguém que tem autoridade } \\
\text { para aplicar a verba nacional na } \\
\text { Guerra }\end{array}$ \\
\hline
\end{tabular}




\begin{tabular}{|l|l|}
\hline $\begin{array}{l}\text { Fala ao Pato que, o Rato está fazendo riquezas com contratos de café no } \\
\text { exterior, enquanto o Pato vive na pobreza (p.21) }\end{array}$ & $\begin{array}{l}\text { - Não fez fortunas, comparado aos } \\
\text { Ratos e Gatos desonestos e } \\
\text { corruptos }\end{array}$ \\
\hline $\begin{array}{l}\text { É aconselhado a jogar na política, começar apostando no nacional e depois } \\
\text { apostar no estrangeiro (p. 24) }\end{array}$ & - Não é de fazer jogo na política \\
\hline $\begin{array}{l}\text { É aconselhado a passar a ser milionário, e depois que se transformar num } \\
\text { grande capitalista, usar uma pistola para defender a lavoura, sua } \\
\text { propriedade, para a Glória do Brasil, ou seja, como capitalista, deve } \\
\text { defender os próprios interesses (p.25) }\end{array}$ & - Não milionário \\
\hline $\begin{array}{l}\text { É aconselhado a ser um Gato refinado, pois a época é do Avança, ou seja, } \\
\text { de avançar como Gato (p. 26) }\end{array}$ & $\begin{array}{l}\text { - Não é beneficiado com a política } \\
\text { do Avança } \\
\text { - Não avança, fica na retaguarda }\end{array}$ \\
\hline
\end{tabular}

Fonte: FERNANDES BARBOSA, 1949.

Em síntese, no decorrer do relato épico, o Eu-lírico narrador parece aplicar um jogo discursivo, um jogo de "Gato e Rato", como se, talvez, intencionasse pegar o "Pato" em alguma armadilha. Vejamos abaixo o anagrama que sintetiza:

Figura 1: Anagrama do jogo discursivo de "Gato e Rato" aplicado ao "Pato"

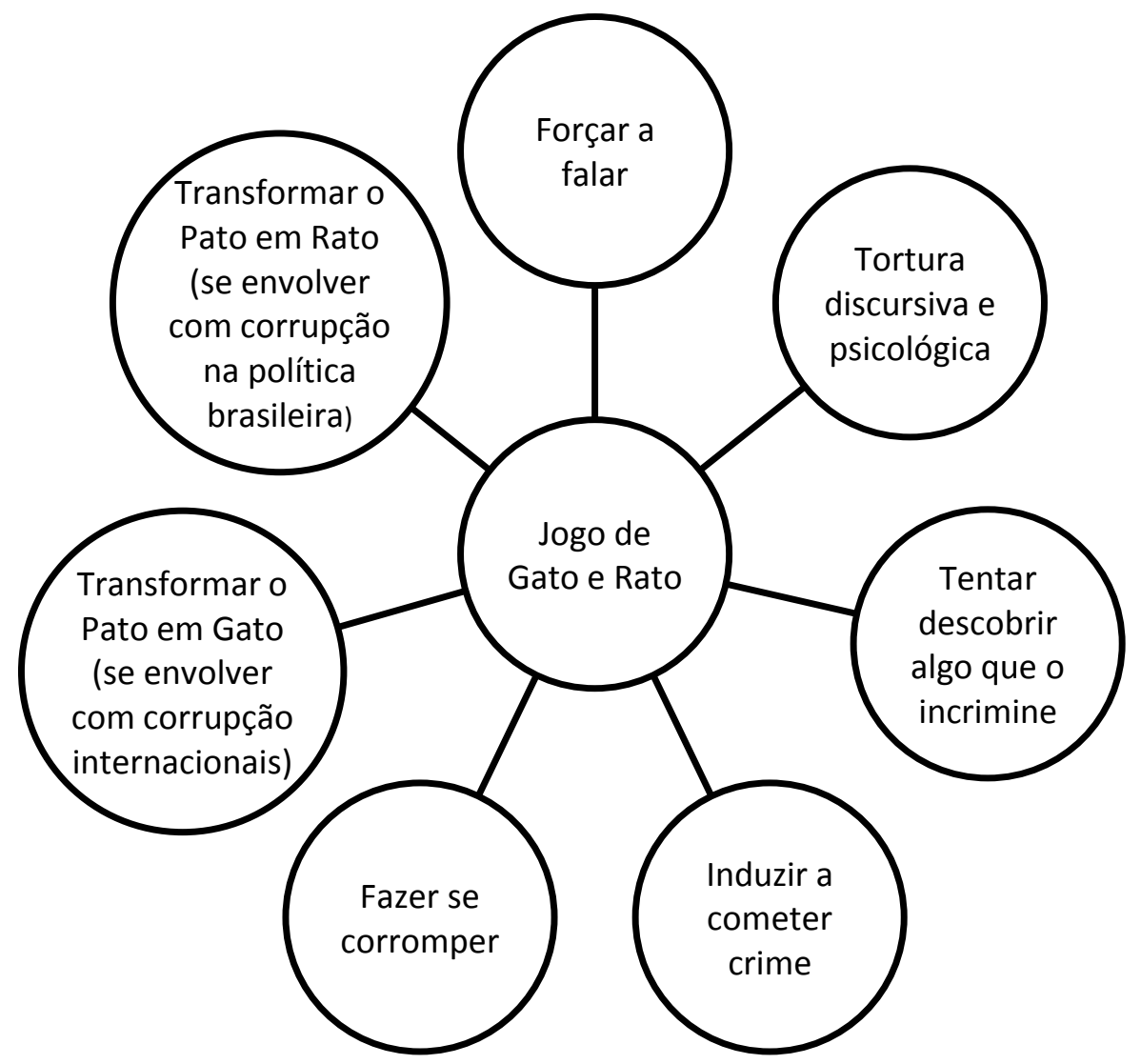

Fonte: Elaboração própria a partir da análise de Os "Gatos" e o "remédio" (1949) 
Findada a jornada psicológica, e por não conseguir arrancar do "Pato" palavra alguma, sem conseguir corrompê-lo, e por não encontrar nada que o incrimine, o eu-lírico / narrador reconhece a Honestidade do Pato e o exalta. Vejamos abaixo, no poema final que derruba as máscaras da ironia e exalta o "Pato" por sua honestidade e seu caráter ético e moral.

Tenho gasto saliva, inutilmente, E todo meu latim pregado em vão...

De um homem sério que nasceu decente, Não é possível se fazer ladrão.

A bandalheira pode estar na frente, Convidativa como um chimarrão, Porque passa meu Pato indiferente, Sem a mais leve cócega na mão.

A causa dessa fibra extraordinária, Provém de uma infecção hereditária, Que trouxeste na corda umbilical.

E que adianta, amigo, meus conselhos, A quem reflete, assim como espelhos, A figura robusta da moral?

(FERNANDES BARBOSA, 1949, p. 27)

Conforme explicado quando analisamos o sentido de ética moral nesse poema, corresponde à ideia no sentido de $\eta \theta 0 \zeta$ (êthos) que está mais próximo do que se conhece por ética, isto é, de "modo de ser" e de "caráter". Durante essa jornada psicológica, e apesar das investidas corruptíveis do eu-lírico / narrador, o "Pato" parece se manter firme e não se corrompe, ou seja, ele parece não se se deixar influenciar pela corrupção. Por outro lado, a "atitude de silenciar também pode revelar habilidade em se desviar de armadilhas ou ciladas arquitetadas por pessoas que ficam espreitando o outro em busca de uma falha moral e ética para desmoralizá-lo socialmente" (OLIVEIRA, 2020, p.90). Assim, o silêncio pode ser visto como um ato de heroísmo.

Pensando no sentido "moral e ético" percebe-se

os traços caricaturais da ironia, sob a ótica do eu-lírico / narrador: de um lado, percebem-se aqueles que são extremamente corruptos; de outro, aquele é extremamente honesto, ou aparenta ser. No poema citado acima, percebe-se a exaltação do Pato por suas virtudes morais, porém o eu-lírico / narrador, pode também estar sendo irônico, pois trata a honestidade como algo inato ao ser 
humano que provém de uma infecção hereditária. Na verdade, parece que ele está atribuindo mais um valor negativo à identidade do eu-lírico / narrador ao qual representa, pois este parece desconhecer que o moral não é algo inato, mas desenvolvido ao longo da vida humana, a partir de trocas experiências coletivas e sociais. Assim, o paradoxo no poema revela a outra face da ironia e a descrença do eu-lírico de encontrar um cidadão honesto naqueles tempos de crises no século XX (OLIVEIRA, 2020, p.90).

Mesmo assim, considerando esse possível aspecto negativo, o que revela a fragilidade do herói, e le que o "Pato", por ser um herói coletivo, também pode ser um reflexo do próprio "eulírico/narrador", sua preocupação com os problemas sociais, seu engajamento, sua mudança que revela uma evolução de sua condição humano existencial, são superiores às suas possíveis fraquezas. Assim sendo, seu caráter heroico é ratificado no poema seguinte:

Ás veze, sem querer, fico descrente, Dêste país em que gatuno é mato, Que brota cada vez mais florescente, Quando se funda um novo Sindicato.

Mas creio que o Brasil irá pra frente, Pois tenho fé em meu Honesto Pato, Que prefere viver modestamente, Do que subir, na vida, como GATO,

Às mãos imaculada do Honesto, Ponham o que o Brasil tenha de resto, A sombra da pilhagem que sofreu.

Pra que amanhã as trêmulas velhinhas, Não digam às suas cândidas netinhas:

- Brasil que estava aqui, GATO comeu!

(FERNANDES BARBOSA, 1949, p.28)

Logo, observa-se que o heroísmo do "Pato" é confirmado quando o eu-lírico / narrador manda que entregue nas "mãos imaculadas do Honesto" o que o "Brasil tenha de resto", ou seja, que entregue nas mãos do "Pato" o que sobrou do Brasil antes que seja tarde e o país seja devorado pelos GATOS, que poderia comprometer, ainda mais, o futuro da Nação.

\section{Considerações finais}

Conforme foi mostrado neste trabalho, por meio da análise, a obra Os "Gatos" e o "remédio" (1949), de Fernandes Barbosa, pode ser lido como um livro de poemas, mas, também 
pode ser lido como um longo poema narrativo que relata a história da Nação no período pós guerras e pós Estado Novo. Na obra, percebe-se os aspectos épicos que a coloca diretamente em diálogo com o Gênero épico, são eles: proposição, invocação, divisão em cantos, planos histórico, mítico e literário, e heroísmo épico. Assim sendo, apontamos, nessas últimas considerações a importância de desenvolvimentos de estudos voltados a analisar com mais profundidade, que a permitida em um artigo, tais aspectos épicos, com ênfase, principalmente, no plano histórico, que precisa ser melhor explorado, e o heroísmo épico, devido o caráter ambíguo dos personagens do eu-lírico /narrado e do Pato.

Cabe salientar também, a importância de desenvolver trabalhos voltados à análise da intertextualidade literária em Os "Gatos" e o "remédio", que embora percebida, não foi abordada sob a justificativa de não deixar o texto demasiadamente longo. Nesse sentido, os principais intertextos identificados foi Os Miseráveis (1862), de Victor Hugo - por causa dos referentes a "Gato" e "Rato", e da linguagem filosófica, política e religiosa, e pela filosofia dos conselhos Dom Casmurro (1899), de Machado de Assis - por causa da filosofia Humanitismo e da frase "Ao vencedor, às batatas!" - e O primo Basílio (1878), de Eça de Queirós- pela referência a Acácio Conselheiro.

\section{Referências}

Referências literárias

BARBOSA, Nilo Fernandes. Os 'gatos' e o remédio. (Edição com correções manuscritas feitas pelo próprio autor) 1.ed. Cachoeira do Sul - RS: Sociedade Gráfica Editora, 1949.

Referências a documentos

Os Gatos e o Remédio: Elogiosa critica do poeta uruguaio Julio Casas Araujo. Recorte de Jornal. In. Documentos disponíveis no Museu Municipal de Cachoeira do Sul - RS. Cachoeira do Sul / RS, 1949.

FROTA, Aquino; MESQUITA, Oliveira; SPALDING, Walter, et al. Notas e comentários sobre Os Gatos e o Remédio (1949). In. Documentos disponíveis no Museu Municipal de Cachoeira do Sul - RS. Cachoeira do Sul / RS, 1949.

Referências críticas e teóricas 
GILBERT, Martin. A história do século XX. Trad. Carolina Barcellos, Ebreia de Castro Alves. 1.ed. São Paulo: Planeta, 2016.

RAMALHO, Christina. Poemas Épicos: estratégias de leitura. Rio de Janeiro: Uapê, 2013.

SILVA, Anazildo Vasconcelos da. Semiotização literária do discurso. Rio de Janeiro: Elo, 1984.

SILVA, Anazildo Vasconcelos da; RAMALHO, Christina. História da Epopéia Brasileira: teoria, crítica e percurso. Vol-1. Rio de Janeiro: Garamond, 2007.

. História da Epopéia Brasileira: da origem ao século XVIII. Vol-2. Aracaju: Artner, 2015.

SILVA, Anazildo Vasconcelos da. Formação épica da literatura brasileira. 2.ed. Jundiaí, SP: Paco, 2017.

MASSAUD, Moisés. Dicionário de termos literários. São Paulo: Cultrix, 2004.

A análise literária. 17ạ reimpr. Da 1a ed. da 1969. São Paulo: Cultrix, 2008.

OLIVEIRA. Ellen dos Santos. Discurso literário, ética moral e política em Os 'Gatos' e o remédio (1949), de Fernandes Barbosa. In. Literatura, ética e política. (recurso eletrônico) QUEIROZ, Mylena; FIGUEIREDO, Annie.(Org.) Alagoinhas; Bordô-Grená, 2020, p.77-93.

RONECKER, Jean Paul. O simbolismo animal. São Paulo: Paulus, 1997.

Artigos de Jornais

FENNER, Mildo Léo. Obra revisitada. In. Jornal do Povo, 1989. 